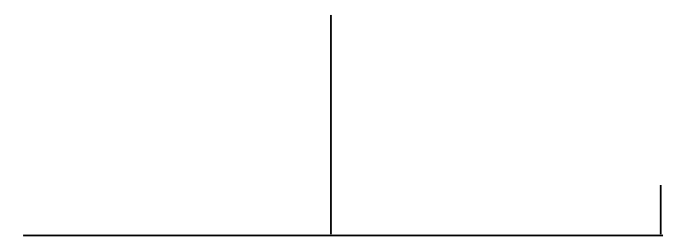

Rev. Latinoam. Psicopat. Fund., São Paulo, v. 15, n. 1, p. 113-137, março 2012

\title{
Instruções sobre como controlar os insanos e de trabalhar para sua cura nos Asilos que lhes são destinados*
}

Jean Colombier

François Doublet

\section{Introdução}

É para os Seres mais fracos e mais infelizes que a Sociedade deve dar maior proteção e mais cuidados; assim, as crianças e os Insanos sempre têm sido assunto do interesse público: as primeiras, pela atenção natural que lhes dedicamos e pela esperança que elas nos inspiram, excitam esta consideração tenra e ao mesmo tempo ativa que só precisa ser esclarecida para vivificar de maneira útil esta origem fecunda da prosperidade de um Estado; se ainda não conhecemos ou praticamos todos os meios que possam conservar o maior número de crianças e tornálas saudáveis e robustas, pelo menos temos certeza de encontrar

* Conforme edição original de 1785. Paris: Imprimerie Royale.

A pontuação e alguns pontos da ortografia foram modernizados para este texto. As maiúsculas, que algumas vezes faltam no caso de uma palavra idêntica repetida, foram transcritas conforme o original.

Tradução de Christian Greis. 
sempre entre os homens uma grande disposição em empregar tudo o que lhes será apresentado para o sucesso da educação física.

O sentimento que temos em relação aos Insanos é diferente; se eles causam a mais profunda pena pela imagem da miséria extrema que lhes atinge e pela ideia do destino que lhes espera, somos, por assim dizer, levados a fugir deles para evitar o espetáculo aflitivo das marcas horríveis que eles carregam em seu rosto e corpo, do esquecimento de sua razão; e, por outro lado, o medo de sua violência afasta deles todos os que não são obrigados a desles cuidar.

Desta maneira, esta classe de infelizes, ainda que a lastimemos e queiramos oferecer-lhe ajuda, é tratada com menos zelo do que a outra, e é por este motivo que ela exige atenção especial e vigilância do Governo.

Parece que os legisladores antigos reconheceram essa necessidade, estabelecendo uma espécie de Culto religioso a favor dos Insanos para os quais os Povos tinham um grande respeito e todos os tipos de consideração; por piedade ou superstição, eram olhados como seres privilegiados do Céu. Eram hospedados em casa e bem tratados. Este costume cheio de humanidade ainda prevalece em todo o Oriente; ainda existe entre os Suíços do Valais, que tratam com a maior distinção e os olham, por assim dizer, como Santos; os Idiotas, como se fossem Seres desgraçados no físico e moral; mas o que nos impressiona mais é o que foi encontrado entre os Povos selvagens da América.

Se esse favor, que é dificilmente concebível devido à fúria de um grande número de Insanos, pudesse diminuir a sua quantidade ou moderar a violência do seu mal, esses Povos teriam julgado melhor que os Modernos que, reunindo e concentrando todos os tipos de Loucos em um mesmo lugar, parecem, antes, querer se livrar e se proteger deles do que aliviá-los e curá-los; verdade dura, mas necessária no momento em que nós nos esforçamos para realizar a visão de caridade que move o Príncipe que temos a felicidade de ter como Mestre.

As leis romanas proporcionaram a conservação e subsistência dos Insanos sem perder de vista os meios de impedir que eles perturbassem a Sociedade; isto também foi praticado desde então nos países civilizados da Europa, principalmente na França, onde se multiplicaram os asilos para esses infelizes, seja por fundações particulares, ou à custa do Governo.

Mas, por mais que pareçam convenientes esses estabelecimentos, eles só atenuam o medo público e não podem satisfazer a piedade que exige não só a segurança, como também os cuidados e tratamentos que são geralmente negligenciados, o que perturba mais ainda a demência de uns quando ela poderia ser curada, e piora a dos outros, sendo que ela poderia ser diminuída.

Para julgar devidamente este assunto, bastará examinar os Asilos destinados ao tratamento dos Insanos, ou interná-los. 


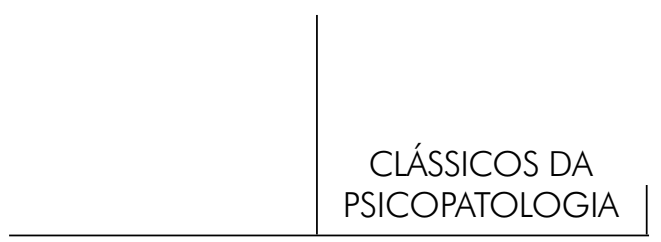

Veremos primeiramente que há apenas no Reino quatro ou cinco locais destinados e preparados para tratar os Insanos; e, se prestarmos atenção, veremos que esses Asilos, talvez com exceção de um só, carecem das coisas mais necessárias ao tratamento ou são muito mal organizados para que sejam úteis; veremos que aí seguem um método rotineiro e quase único, com pouquíssimo sucesso, devido à variedade dos tipos de demência; enfim, só encontraremos um onde, apesar de vários defeitos essenciais, as curas são um pouco apoiadas; mas quais são os dementes que são tratados nessas Casas? São poucos, e na maioria das vezes a doença está apenas no começo; quanto aos outros, não há recursos.

Milhares de Insanos são internados em Manicômios, sem que haja a menor preocupação em administrar remédios: o semiperturbado é confundido com quem o é totalmente; o Furibundo com o louco menos agitado; uns são acorrentados, outros livres em sua prisão, enfim, a menos que a Natureza venha em seu auxílio, curando-os, o fim de seus males é o de seus dias e, infelizmente, até lá, a doença só agrava em vez de melhorar.

Tal é o verdadeiro estado dos recursos, até este momento, para combater o triste estado dos pobres Insanos: o grito da humanidade se ouve a seu favor e um grande número de Asilos se prepara para ampará-los e estabelecer um departamento unicamente dedicado a eles em cada Manicômio, e aí todos os tipos de loucura são tratados indistintamente.

Para obter bons resultados duradouros é preciso não só aproveitar os conhecimentos adquiridos, como também se precaver dos abusos e preconceitos atuais, dispor de novos locais resultantes deste projeto; e, sobretudo, dar aos antigos estabelecimentos um exemplo do qual possam aproveitar e esclarecimentos para que possam se corrigir e aperfeiçoar.

Foi com essa intenção que o Governo ordenou a publicação desta Instrução, que se divide em duas partes: uma visa à necessidade de seguir, em relação aos cuidados e à instalação dos Insanos, um plano diferente do que o adotado; e a outra, traça o procedimento geral do tratamento que deve ser administrado para os diferentes tipos de demência.

\section{Primeira parte}

\section{Referente a como instalar, manter e conduzir os dementes}

Os ricos e prósperos fazem questão de tratar com cuidado, em suas casas, seus parentes acometidos de loucura, antes de decidirem interná-los: esta conduta nos mostra o que os pobres dependem da piedade pública; é preciso primeiramente 
que um pobre Insano seja colocado em um lugar onde receba um tratamento e só após tê-lo seguido sem sucesso é que o doente é mandado para um Manicômio.

Após um tratamento infrutífero, uma família respeitável, ou mantendo-o em seu lar, ou colocando-o em local seguro, dá toda sua atenção para que o infeliz desfrute do conforto necessário, para com a dieta, suas vestimentas ou cama; ela não deixa que o maltratem, propositalmente ou de nenhum outro modo, ela lhe proporciona cuidadores fiéis, com inteligência e probidade, nos quais ela pode confiar; e verifica se o local onde ela o instala é seguro contra eventuais tentativas de evasão, é salubre, e não inspira horror.

Para evitar que a loucura aumente e se torne incurável, esta regra é a única que se pode seguir para os pobres Insanos, e a humanidade não permite que se afaste dela, nem mesmo no Manicômio.

Quando a demência é intermitente ou suave, essa família não abandona o doente; ela procura novos métodos de tratamento, os repete e por esta perseverança obtém, algumas vezes, uma cura perfeita, ou, pelo menos, uma grande diminuição dos acidentes: se este doente tem acessos fortes e de grande violência, ela tenta moderá-los, procurando apoio de pessoas relacionadas à Ciência, mas ela tem ao mesmo tempo muito cuidado para que ele não resida com outro Insano, principalmente se houver perigo, e ela se encarrega de fazê-lo esquecer seu infortúnio, se ocasionalmente ele tiver um momento de lucidez.

É assim que o rico pode ser curado, ou pelo menos levar uma vida menos sofrida, se tiver a infelicidade de ser atacado pela demência: pelo menos não precisamos temer que ela aumentasse pela maneira como o conduzimos, ou por uma funesta comunicação; e os deveres da Natureza e da Sociedade também são preenchidos, usando-se de todos os meios que possam destruir e diminuir a doença, ou tornar o destino do Insano menos deplorável.

Por que então não usar o mesmo para com os pobres? Seria pela impossibilidade do sucesso ou pelas enormes despesas que teríamos que arcar para atingir esse objetivo? Provaremos que estes obstáculos não são reais, será suficiente ler o que se segue para se convencer desta verdade.

As leis que prescrevem prender um Insano que perturba a Sociedade possuem a dupla vantagem de prevenir o crime cometido por uma mão inocente e de fornecer, ao mesmo tempo, uma maneira de socorrer um infeliz cujo estado pode mudar, colocando-o num local conveniente e prestando a ajuda necessária.

São antes de tudo os pobres que exigem o cumprimento destas leis, porque o Povo não tem nem os recursos necessários para conter os Insanos, nem a faculdade de tratar e de fazer tratar esses doentes; deve-se acrescentar ainda que seria frequentemente perigoso deixá-los em suas mãos; mil exemplos 


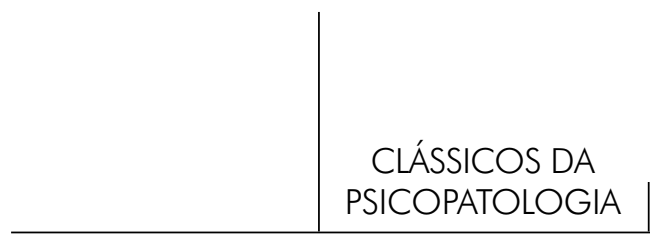

comprovaram este perigo e os jornais reportaram, há pouco tempo, a história de um Maníaco que, após haver degolado sua mulher e filhos, dormiu tranquilamente sobre as vítimas ensanguentadas por seu delírio.

Mas não podemos esconder aqui que se negligencie essa precaução e que os Insanos andarilhos não são sempre detidos, ou porque faltam locais para interná-los, ou porque as Comunidades responsáveis pelo custeio, detenção e pensão do Insano demorem em avisar o Órgão público, ou mesmo se esquivam de fazê-lo.

Podemos evitar estes dois inconvenientes, designando os Asilos e alguns Hospitais em cada Generalidade para receber os Insanos e adotando medidas para que as Comunidades ou outras pessoas encarregadas de declarar a existência de um Insano o façam sempre.

Com respeito à segurança desses infelizes, uma atenção especial é exigida, pois as surpresas assustadoras e as ameaças são muitas vezes perniciosas e agravam sua condição, sobretudo quando são detidos em intervalos de lucidez.

Se as amarrações são às vezes necessárias, seria preciso eliminar o que elas têm de cruel e humilhante; mas os maus-tratos e principalmente as pancadas devem ser considerados atentados dignos de uma punição exemplar.

É sem dúvida bem difícil evitar todos os abusos deste tipo; mas parece que poderiam ser evitados por ordens e vigilância da parte dos Oficiais que comandam os que são encarregados de prender os Insanos.

É também importante dispor convenientemente de locais destinados a receber esses infelizes, que são de dois tipos: uns são destinados ao tratamento e os outros para abrigar os que não estão expressamente sujeitos a ele.

Quanto aos primeiros, não se pode dispensar salas para os vários tipos de Loucos; os Agitados, os Insanos tranquilos e os que estão em convalescença.

É preciso também que as salas sejam arejadas e afastadas do fogo, que cada doente durma sozinho e que haja dependências para banhos.

As pessoas responsáveis por esses pacientes devem ser escolhidas com cuidado, pois suas funções exigem ao mesmo tempo grande força corporal, humanidade, presença de espírito e habilidade; são qualidades difíceis de reunir, e ainda mais de conservar por longo tempo num emprego tão importante.

Sem dúvida ganharíamos muito com respeito à vigilância se conseguíssemos utilizar leitos mecânicos que os doentes pudessem usar sem serem incomodados e que os impedissem de fazer movimentos violentos; mas este recurso, ainda que possível, não é prioritário em um momento em que buscamos retificar o serviço nos pontos mais importantes.

Veremos na segunda parte dessa Instrução tudo que deve ser acrescentado às precauções acima, relativas ao local destinado ao tratamento; o que diremos agora se refere aos locais onde colocamos os Insanos de todo gênero, reunidos em um Manicômio. 
Já observamos acima que apenas isolando os infelizes alienados da Sociedade, não seriam preenchidos inteiramente os pontos de vista que devemos propor e provamos que, em todos os casos, é essencial tratar primeiro os doentes, sobretudo quando a loucura está no início; mas quando empregamos inutilmente todos os recursos necessários para a cura, ou quando a demência é antiga, não devemos acreditar que os doentes não serão curados, pois a experiência demonstra que acontecem, às vezes, transformações felizes nesses indivíduos, que recuperam totalmente a razão quando menos se espera.

Julguemos a partir daí como é importante não colocar obstáculos a essas curas naturais e que devemos reprovar todas as manobras que, em vez de atingir esta meta, apenas mergulham esses infelizes em uma alienação mais grave do que a que tiveram no Manicômio.

Portanto, é preciso que os locais em que sejam instalados e os cuidados que tomamos concorram para acalmá-los, para a cura e para a melhoria do estado dos pacientes:

1) É preciso haver nesses lugares ar puro e a água deve ser salubre. Estas precauções são ainda mais importantes pelo fato de a maioria dos Insanos comerem muito poucos alimentos sólidos e se alimentarem, por assim dizer, somente de ar e água.

2) É preciso fazer caminhadas que lhes proporcionem serenidade e liberdade de respirar ar livre; porque, por mais Insanos que sejam, a maioria desses infelizes tem ciência de seu cativeiro e do carinho que eles recebem; esses passeios devem ser na sombra, para evitar que se exponham ao Sol; porque a insolação prolongada causa vertigens a todas as pessoas e resultou várias vezes em loucura; foi o que atingiu os habitantes de Abdère, por terem assistido durante o calor do Sol à representação de Andrômeda de Eurípedes; tal foi, segundo alguns historiadores, a origem da doença de Charles VI, Rei de França.

3) O prédio será dividido em vários cômodos, com um pátio para cada um. Cada cômodo formará um quadrado cujo centro será o pátio e os quatro lados serão construções altas em andar térreo.

Haverá uma galeria coberta interna ao longo dos quatro lados do prédio e este corredor, assim como os cômodos, se encontram no mesmo andar, mas três pés acima do pátio.

Nos quatro lados do quadrado haverá quartos ou dormitórios para reunir os Insanos durante o dia; e o resto do prédio será dividido em acomodações de oito pés quadrados, que serão iluminados por uma lanterna com grelha colocada na abóbada.

Cada acomodação terá um leito sólido, chumbado na parede; colchão de palha de aveia, um travesseiro com o mesmo material e um cobertor; e no leito haverá alguns anéis de ferro, caso venham a se tornar necessários. 


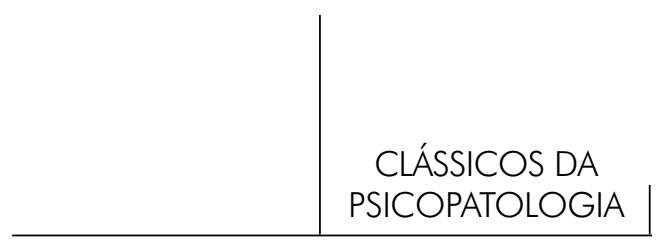

Perto da porta, haverá um banco de pedra fixo e outro menor no quarto. No centro do pátio haverá um local para várias banheiras de pedra, com água quente e fria trazida por bombas dos reservatórios vizinhos.

Quanto às latrinas, além das que já existem em cada cela, haverá uma no meio de cada lado do quadrado, dispostas de maneira que os Insanos não possam se jogar nelas e nem se ferir. Uma bomba lateral servirá para lavá-las quantas vezes for preciso; haverá um duto sob as latrinas dos quartos ou celas para levar toda a imundície por meio de água corrente.

Este tipo de construção, tão salubre quanto possamos desejar, isola cada Insano, mantém ao mesmo tempo a maior limpeza e possibilita dar banho aos que necessitam desse tipo de terapia.

Haverá também um departamento, ou alojamento, para os Imbecis, um segundo para os Loucos violentos, um terceiro para os Loucos tranquilos e um quarto para os que tiverem momentos de lucidez de certa duração e que pareçam estar a caminho da cura.

Para estas divisões multiplicadas, reuniremos os Insanos com sintomas análogos e os separaremos daqueles com sintomas opostos; ao mesmo tempo, afastaremos de ambos os que estão em condição de sentir a bondade da Sociedade e assim evitaremos as consequências funestas do contágio nervoso que se propaga por imitação.

Esta última precaução é mais necessária ainda pelo fato de que não podemos ignorar que os cérebros meio transtornados e os convalescentes duvidosos são extremamente suscetíveis a impressões de mania, a cujos exemplos eles estão permanentemente expostos.

E quando levamos em consideração que esse contágio atinge até as mentes mais sadias; que a maioria das pessoas que cuidam dos Insanos, após algum tempo, fica com a fisionomia fortemente perturbada; que muitos deles se tornam Imbecis e alguns mesmo Maníacos, como verificamos em Bicêtre e na Salpêtrière, entende-se o quanto esta separação é importante.

Mas, enfim, quando o poder de imitação deste tipo não é nem tão grave, nem tão certo como acabamos de provar, a necessidade de classificar e separar os diferentes tipos de demência não seria menos demonstrada aos olhos da humanidade, uma vez que esta separação pouparia pelo menos os que têm intervalos de lucidez, um momento de consciência fugaz e desesperada de sua miséria.

4) A dieta dos Insanos foi até hoje absolutamente negligenciada, embora saibamos há muito tempo quanto o alimento influi sobre a moral: o Brâmane, que se alimenta só de leite e vegetais, tem horror a sangue e seus costumes são muito brandos; o Selvagem caçador e antropófago gosta de carnificina e todas as suas 
ações são bárbaras. Algumas plantas nos deixam frenéticos, outras nos mergulham na imbecilidade: os Orientais, com o ópio e outras drogas mencionadas por Kœmpfer, procuram por livre e espontânea vontade, delírios furiosos ou êxtases deliciosos; enfim, os bêbados e os devassos sofrem frequentemente de manias epiléticas: não devemos concluir que uma dieta mais líquida, moderada e fundente terá efeito contrário ao das substâncias amargas, estimulantes, quentes e venenosas e que em consequência é preciso proibi-las aos Insanos?

Então é preciso ajustar sua dieta de acordo com esses pontos de vista.

A bebida habitual será uma mistura de cevada adoçada com alcaçuz e acidulada com cremor de tártaro; se permitirmos o vinho algumas vezes, será somente uma exceção; mas a aguardente é perniciosa, nunca será permitida nos departamentos.

Serviremos carne duas vezes por semana; nas outras vezes, a refeição constará de legumes cozidos na água com manteiga, como cenouras, pepinos, azedinhas, chicória, favas e lentilhas, cuidando para não dar duas vezes por dia legumes farinhentos.

A quantidade de pão é de uma libra e meia por dia e os que recusarem alimentos sólidos receberão uma pinta de leite; como é preciso que cada Insano siga a dieta que seja melhor para ele, o Médico ou Cirurgião prescreverá a quantidade diária dos alimentos citados acima.

5) As roupas dos Insanos são mais difíceis de controlar do que sua alimentação, porque esses infelizes as rasgam e, por outro lado, a maioria não quer usá-las; provavelmente seja este o motivo de termos negligenciado esta parte essencial do regulamento do Manicômio, onde se observa que alguns estão quase nus e outros cobertos com andrajos.

Parece, no entanto, que para manter a saúde, e mesmo restabelecê-la, é preciso manter esses infelizes suficientemente e corretamente vestidos.

Eles terão uma camisa branca a cada oito dias; os homens e as mulheres usarão uma veste longa, fechada por baixo; ambos receberão uma camisola amarrada atrás com laços, uma calça larga, como a dos Marujos, e um boné de homem.

Estas roupas serão de pano grosso, forradas no inverno e sem forro no verão; suas meias serão de estopa, e seus calçados, sandálias.

Os Insanos retidos em seus quartos terão em vez de calças, uma meia-saia de pano grosso, como a dos Cervejeiros e dos Padeiros.

Este tipo de roupa pode ser usado por todos os Insensatos, já que é muito mais fácil de tirar do que as outras e, com vigilância adequada, não poderão tirá-la de maneira errada ou rasgá-la.

Devemos observar aqui que é essencial, em todos os aspectos, que a cabeça dos Insanos seja raspada, porque sem esta precaução os vermes se instalam e, 
além disso, as loções para cabeça, tão necessárias para a maioria das demências, são muito mais eficazes quando não há cabelos.

6) Os cuidados que devemos tomar quanto aos Loucos que não são expressamente sujeitos ao tratamento devem ao menos ter uma relação com ele, pois alguns podem se curar com o tempo só pela dieta, enquanto vários outros exigem cuidados especiais relativos à sua situação presente, e que enfim há muitos que devam ser submetidos novamente ao tratamento e que se curam após o segundo ou terceiro.

Não basta, portanto, tratar de maneira geral os Insanos internados no Manicômio, é preciso também que sejam classificados conforme seu estado de saúde e segundo as opiniões que se tem sobre seu tratamento presente, próximo ou distante.

Primeiramente, a categoria dos Imbecis sem nenhuma esperança de cura, instalada em uma ala separada, recebe apenas os cuidados gerais que o senso de humanidade prescreve e que já abordamos acima.

Quanto aos outros, nós os preparamos para o tratamento por diversos meios, mas principalmente pelos banhos mais ou menos repetidos que são prescritos pelo Médico ou Cirurgião, assim como alguns remédios que muitas vezes levam à cura sem chegar aos meios heroicos, como se verá na segunda parte.

Os oficiais de saúde farão uma visita diária para prescrever a cada um deles o que for conveniente em dieta e medicamentos, e para fazer a triagem dos que estiverem aptos a seguir o tratamento geral.

Os Vigilantes e Servidores destinados às salas dos doentes em tratamento devem ser atentos, prudentes, serenos e firmes; essas qualidades não são menos importantes para os que guardam e cuidam dos Insanos nos Manicômios. As amarras que devemos usar exigem habilidade e prudência. As pancadas devem ser proibidas e punidas severamente.

Estes Guardiães devem relatar aos Oficiais o progresso bom ou ruim que observam nos Insanos; devem manter o máximo de limpeza nos dormitórios, pátios, quartos, latrinas e roupas.

Deve haver uma regra que defina os horários dos banhos, a distribuição dos alimentos, dos medicamentos, a abertura e o fechamento das acomodações, a troca das roupas do corpo e da roupa de cama: no inverno, os dormitórios dos Insanos serão aquecidos enquanto eles estiverem lá e eles devem ser suficientemente vigiados o tempo todo.

Este é o plano que se deve seguir para trazer um grande número de Insanos à razão e responder, ao mesmo tempo, aos aspectos humanitários que devem ser utilizados com esses infelizes. Vamos agora falar do tratamento especial exigido para os Doentes, entrando em todos os detalhes que tenham ligação essencial com aquele discutido até agora. 


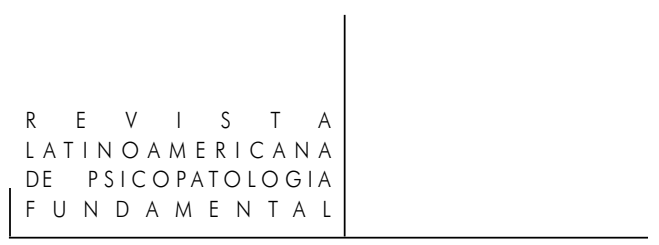

Segunda Parte

Tratamento

\section{Classificação das doenças que podem afetar a mente. Em quatro tipos}

As doenças que podem afetar as faculdades intelectuais do homem são numerosas: umas pervertem o sentimento, outras perturbam a imaginação ou enfraquecem a memória; enfim, as mais frequentes e perigosas são as que destroem a razão.

Não vamos aqui descrever as diferentes doenças, mas apresentaremos a tabela dos sintomas e do tratamento das mais características, ou porque as outras podem ser relacionadas a elas, ou porque são as únicas que têm assistência do Governo.

Todos os diferentes graus de alienação da mente podem se relacionar a quatro tipos de doença: Frenesi, Mania, Melancolia e Imbecilidade.

\section{$1^{\circ}$ tipo: O Frenesi}

O frenesi é um delírio violento e contínuo, acompanhado de febre: ou é um sintoma alarmante que se desenvolve em doenças agudas, ou é produzido por uma afecção primitiva do cérebro e se torna uma doença grave. Mas, de qualquer tipo que seja, é com frequência a fonte de onde decorrem as outras doenças que afetam a cabeça, como a mania e a imbecilidade, que são as consequências mais frequentes.

\section{Divisão do frenesi. Frenesi sintomático ou falso}

O frenesi que depende de outra doença é chamado sintomático: resulta de febre maligna, quando há um transporte da matéria morbífica ao cérebro; ela se manifesta em pleurisias onde o diafragma é afetado, como provaram vários Observadores célebres e, entre outros, Boërhaave e M. Boucher: ele é comum na febre tifoide e na varíola: as dores fortes, como a de ouvido, causam frenesi e esta é uma observação de Hipócrates. Enfim, Sydenham mostrou que causas opostas poderiam causar o mesmo efeito, demonstrando que a fraqueza causa algumas alienações, acompanhadas de fúria; mas a observação deste célebre Autor se relaciona mais à mania do que ao frenesi, como veremos adiante. 


\section{CLÁSSICOS DA PSICOPATOLOGIA}

Podemos concluir três coisas deste tipo de frenesi falso ou sintomático: a primeira, que o reconhecemos pelos sinais de outra doença e que não é uma doença primária; a segunda, que todo o seu tratamento consiste em conhecer bem as doenças de que ela é o resultado; a terceira, o falso frenesi mal controlado, ou que termina mal, tem os mesmos efeitos que o frenesi real.

\section{O falso frenesi tem os mesmos efeitos que o real sobre a compreensão humana} $O$ frenesi real, seus sinais, seus caracteres e efeitos

Este se reconhece pelos seguintes sinais: ele é súbito e violento; a dor de cabeça é forte e é acompanhada de inflamação; o corpo é afetado por pletora; os olhos e o rosto ficam vermelhos, há sonhos assustadores ou insônia e a demência é evidente desde os primeiros momentos. Os jovens, especialmente os de temperamento bilioso-sanguíneo, ou os viciados em bebidas alcoólicas, estão sujeitos a isto. É frequente em países quentes, conhecido como calentura: logo, o pulso fica muito rijo e rápido, as ideias transtornadas e os desejos e ações do doente não têm propósito racional. Sua voz muda, as palavras são bruscas e temerárias, seu olhar é feroz; algumas vezes, sangue sai pelas narinas. Quando a doença não pode ser contida, o paciente produz um vômito cinza-esverdeado, seus olhos ficam secos; os doentes cospem com frequência e sem decoro; enfim, não evacuam mais, adormecem ou têm convulsões, causando o fim de sua vida do quarto ao sétimo dia. Quando se abre o cadáver, há meninges inflamadas, tumores gangrenosos no cérebro, ou um líquido icoroso que roeu a matéria.

\section{Tratamento do frenesi real}

Dentre as doenças do cérebro, esta terrível doença é a menos difícil de curar; mas é preciso remediá-la o quanto antes, porque o foco do mal estando localizado em um órgão tão delicado quanto o cérebro, há só um caminho para a cura: a resolução.

Para consegui-la, é preciso iniciar com sangrias amplas e começar por aquelas do pé, repetindo-as duas ou três vezes; em seguida, passaremos para aquelas da artéria temporal e jugular, mantendo-as amplas e copiosas. A Natureza demonstrou a necessidade de sangrias fortes nessas ocasiões, curando os Frenéticos por hemorragias abundantes.

Se o doente tem propensão a hemorroidas, a sangria deverá ser feita por meio de aplicação de sanguessugas no ânus: em todos os casos, esta parte deve ser observada, pois as hemorroidas são muitas vezes críticas nesta doença, e esta crise tem que ser bem cuidada. 
As bebidas serão abundantes, frias, diluentes e antiflogísticas. No intervalo de cada sangria haverá, se possível, duas lavagens, uma purgativa e a outra emoliente.

A partir do momento da invasão da doença, a cabeça será raspada ou os cabelos cortados; em seguida, será colocado um curativo, chamado de boné de Hipócrates, que deverá estar sempre molhado, umedecendo-o com esponja embebida de uma mistura de água e vinagre frio. É reconhecido que a barriga deve ser bastante relaxada: na ausência de uma diarreia natural, que várias vezes foi benéfica, providenciaremos uma artificial dando um laxante após a sangria. Este laxante será um tanto forte, mas corrigiremos o efeito dando sementes de anis ou de outra erva e um calmante no mesmo dia. No dia seguinte à tomada do laxante, o doente tomará um banho morno e uma ducha fria, mais ou menos longa, dependendo da gravidade e grau do mal. Enfim, serão aplicados, logo em seguida, amplos vesicatórios nas pernas, porque foi comprovado que as dores nas pernas são favoráveis a essa doença.

\section{Bom tratamento do frenesi no l'Hôtel-Dieu de Paris: ele pode ainda ser aperfeiçoado}

É devido a esse método ou a algum semelhante que certos Hospitais devem sua reputação pelo tratamento dos Loucos; o do Hôtel-Dieu de Paris é o melhor, mas ainda faltam coisas essenciais: um local mais amplo para separar os doentes, pois a confusão os impede de seguir bem o tratamento; um local mais arejado, tão necessário a esses infelizes que têm a cabeça fervendo; mais banheiras, colocadas num local não tão perto dos doentes e no qual o ar não seja tão parado ou sufocante.

Após sete ou oito dias no frenesi real e, bem mais tarde, no frenesi falso, a febre cessa; e se a resolução não ocorre, ou não for completa, o delírio furioso persiste com maior ou menor força. Algumas vezes, mas raramente, a obstrução dos humores não é forte e a Natureza se encarrega de curá-lo, como no caso da imbecilidade que resulta das distintas febres malignas, que se dissipa por etapas. $\mathrm{Na}$ maioria dos casos, quando a resolução não é feita de maneira adequada, permanece uma mania mais intensa ou uma imbecilidade. É assim que Van-Swieten a observou, não somente após os frenesis reais, mas também após os falsos. Entre elas, uma das mais comuns, conforme este excelente Observador, é a produzida pela supressão de lóquios em mães que deram a luz recentemente. 
Quando o frenesi não termina pela resolução, ele se transforma em mania Segundo tipo. A Mania: natureza, sintomas e diferenças da Mania

A Mania é um delírio constante, sem febre; porque se houver febre, ela não depende de afecção do cérebro, mas de outras circunstâncias que acontecem por acaso. Os Maníacos têm por sintoma uma força corporal surpreendente, capacidade de suportar fome, a vigília e o frio por muito mais tempo do que os outros homens, sadios ou doentes; seu olhar é ameaçador, seu rosto sombrio, seco e famélico: úlceras nas pernas lhe são familiares, suas excreções muitas vezes cessam; eles têm pouco sono, mas ele é profundo; sua vigília é agitada, turbulenta, cheia de visões, de ações desordenadas e algumas vezes perigosas para as pessoas próximas. Alguns têm intervalos bastante tranquilos; outros têm acessos contínuos ou repetidos.

O cérebro dos Maníacos é seco, duro e quebradiço; às vezes, a parte cortical é amarela; outras vezes, vemos abscessos; enfim, os vasos sanguíneos estão inchados com sangue negro, varicoso, pegajoso em alguns lugares e dissolvido em outros.

Causas diversas da Mania

Esses diferentes distúrbios no cérebro têm várias causas; ora é um núcleo inflamatório que não se resolveu, como no caso da mania que resulta da frenesi real; ora é uma metástase de um humor morbífico qualquer, como no frenesi falso; o calor, a inanição, o veneno, as paixões causam diretamente a mania; e, devido a estas causas múltiplas, não nos surpreende que este tipo de loucura seja tão comum.

\section{Tratamento geral da Mania}

A mania que sucede ao frenesi, a que se produz por metástase sanguínea ou mesmo por metástase humoral entre as pessoas robustas; a que é causada pelo calor, por uma paixão violenta ou por uma queda, devem primeiramente ser tratadas como o frenesi real; sangrias repetidas, laxantes, banhos mornos, duchas frias, cautérios, sedenhos ou úlceras artificiais, eis o procedimento geral; mas há, entretanto, uma grande diferença na maneira de aplicar estes vários remédios ao frenesi ou à mania. 
Observações sobre a sangria

1) Embora as sangrias devam ser feitas sem hesitação na mania, devemos nos restringir mais do que no caso do frenesi, que é uma doença muito mais grave e primária; esta restrição se torna ainda mais necessária quando a doença for mais antiga. Quando se sangra em excesso na mania, vê-se, na verdade, o furor se dissipar; mas esta melhoria aparente é falsa, pois é causada pelo enfraquecimento da pessoa e ela muitas vezes cai em imbecilidade incurável; porém, a sangria deve ser considerada um excelente remédio na mania, quando não se extenua o doente e se tira o sangue dos lugares convenientes.

Como devemos limpar o cérebro, em lugar de diminuir a massa dos líquidos, é preferível tirar o sangue da cabeça abrindo a têmpora ou jugular, ou aplicar sanguessugas ou ventosas.

Hildan relata vários casos de curas súbitas pela abertura da artéria temporal, ou aplicação de sanguessugas na mesma parte; mas a sangria parece mais eficaz quando a mania é causada pela supressão de um fluxo sanguíneo.

\section{Sobre os laxantes}

2) A administração de laxantes é muito mais importante do que a sangria; porque há muitas manias que podem ser curadas sem tirar sangue, enquanto há poucas que não precisam de laxantes, mesmo repetidas vezes, para diminuir a rarefação do sangue, atenuar e expulsar os fluidos pegajosos e espessos. Mas para que os laxantes possam fazer o efeito que se espera, é preciso que sejam precedidos de bebidas calmantes e fundentes, de uma dieta umectante e de banhos mornos, com a mesma indicação: em seguida, serão administrados gradualmente os laxantes, começando com os mais suaves, que são os catárticos; em seguida os fortes, aumentando a dose, para chegar aos mais drásticos; corrigindo, porém, o abalo causado por esses remédios ativos administrando, no mesmo dia, um ou dois grãos de ópio.

Médicos de todas as idades se reuniram para aplaudir esta conduta: os Decanos começavam por prescrever epitimo, agárico e outros remédios semelhantes; mas estes laxantes eram, digamos assim, preparatórios. O ponto essencial da cura era o heléboro, como todos fazem. Eles preparavam em Anticire, ilha do Arquipélago, o heléboro preto e branco, para corrigir sua qualidade mais corrosiva: o que é certo, é que curavam muito mais Maníacos do que nós; e é por isso, diz Lorry, que eles não eram obrigados a internar estes infelizes como nós o fazemos. Alguns exemplos felizes da aplicação deste remédio, em casos desesperados, observados por este sábio Médico; várias outras tentativas foram 


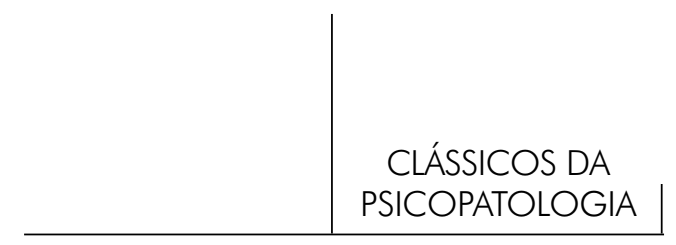

igualmente favoráveis nas mãos de Charlatões, por intermédio deste mesmo medicamento. São fatos autênticos e poderosos que devem nos levar a recorrer à preparação de heléboro, quando os doentes tiverem sido bem preparados e que os primeiros laxantes tiverem falhado.

Sydenham obteve grande sucesso na cura dessas doenças, fazendo uso frequente da raiz de brionia, cujas propriedades são muito semelhantes às do heléboro. Este médico célebre administrava raiz de brionia diluída em leite, ou meia onça numa infusão de vinho. Um Cirurgião de Paris que prometeu, há alguns anos, curar os Doentes mentais, tratava em Bicêtre de vários Maníacos, alguns dos quais tiveram uma melhora significativa, ainda que de pouca duração; o remédio que ele administrava era um laxante forte e talvez tivesse tido mais sucesso se tivesse perseverado nesta administração.

Os limites desta instrução não permitem expor os motivos pelos quais poderíamos demonstrar a necessidade de retomar o heléboro: encontraremos esses motivos em diversos Autores, inclusive no sábio Tratado de Lorry, de Melancholia, onde ele prova que a mania muitas vezes tem sua origem no ventre e na cabeça.

Basta dizer que o heléboro negro pode ser administrado de várias maneiras: primeiramente o extrato de Rudius, do Codex de Paris, numa dosagem de 36 grãos ou dois escrópulos numa solução de maná; em seguida podemos prescrever a infusão de uma onça de heléboro negro em um copo de vinho para ser tomado em duas vezes; poção equivalente a meia dose, de efeito considerável; enfim, a melhor maneira de administrar o heléboro é 18 grãos ou um escrópulo, triturá-los com um pedaço de açúcar e uma gema de ovo e despejar cinco onças de água fervente e uma onça de óleo de anis. Recomendamos heléboro branco apenas para os doentes que não respondem ou têm pouca reação com o heléboro negro; então daremos 12 grãos.

Sobre banhos e duchas

3) Banhos e duchas serão administrados por muito tempo aos Maníacos e o modo de torná-los eficazes é alterná-los com laxantes, isto é, purgar um dia e banhar no outro.

Vemos, nas Memórias da Academia Rural de Ciências, exemplos marcantes de efeitos de aplicações frias na cabeça: um Autor Inglês relata que um Maníaco foi curado pela aplicação de um boné cheio de neve. De todos os fatos que podemos recolher, deve-se concluir que o melhor método é de dar banho moderadamente quente, com gelo ou neve na cabeça e deixá-lo assim por duas horas e após este tempo sua cabeça será descoberta e ele tomará uma ducha com água bem fria.

Rev. Latinoam. Psicopat. Fund., São Paulo, v. 15, n. 1, p. 113-137, março 2012 


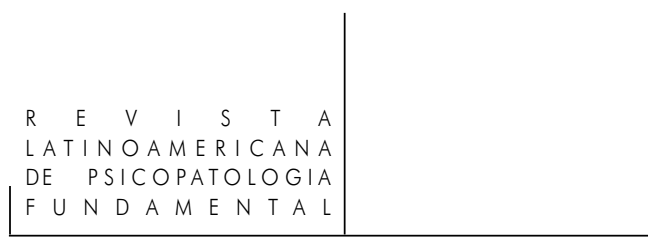

Os cautérios e sedenhos

4) Os cautérios, os sedenhos, as úlceras artificiais serão úteis em todos os casos, substituindo as evacuações difíceis; mas serão muito recomendáveis, especialmente quando a mania for produzida pela metástase de um humor virulento: tentamos neste caso inocular sarna, este ponto de vista não deve ser negligenciado.

\section{Divisão de doentes tratados em três tipos}

Quando os diferentes Maníacos citados acima forem submetidos ao tratamento que acabamos de detalhar, observaremos o efeito que este tratamento teve sobre eles, e conforme o efeito do tratamento, poderemos dividir em três tipos: os que não têm mais sintomas, os que só tiveram alívio e os que não obtiveram nenhuma melhora por meio do tratamento.

\section{O que é preciso fazer com os curados}

Os doentes do primeiro tipo ou os convalescentes serão completamente separados dos Insanos; eles receberão certa liberdade, serão submetidos a banhos frios e mais esporadicamente a duchas, eliminando-as cada vez mais; poderão tomar sucos antiescorbúticos para refrescar seus corpos exaustos e emagrecidos; prescreveremos laxantes de vez em quando e eles acabarão tomando leite.

\section{O que fazer com os tranquilizados}

Os do segundo tipo, ou os tranquilizados, tomarão durante algum tempo caldo ou aperitivos de apozema, misturados com sal neutro, como o de Glauber, ou água mineral, seguindo as mesmas indicações; continuaremos com os banhos mornos frequentemente, usaremos bolos ${ }^{1}$ de sabão para proporcionar a fluidez dos humores. Após algum tempo, se a estação for favorável, recomeçaremos o primeiro tratamento; se os sintomas de pletora e secura persistirem, insistiremos com as sangrias; se a melancolia ou bílis parecem persistir e se a pessoa não for forte, faremos pouca ou nenhuma sangria.

1. Pílula grande, de consistência pastosa e formato ovoide, que se deglute de uma só vez. (N. da T.) 


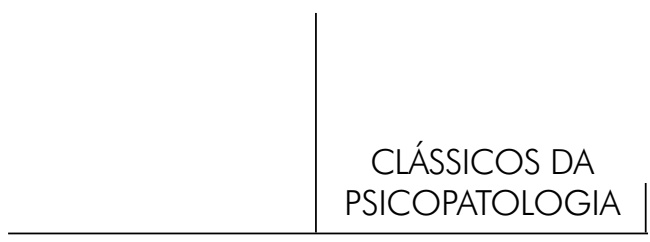

O que fazer com os doentes rebeldes

Estão incluídos no terceiro tipo os que já foram submetidos várias vezes ao tratamento ativo sem sucesso, e que não poderiam mais segui-lo sem risco. A Medicina apresenta poucos recursos verdadeiros para esses doentes; muitos medicamentos foram elogiados como sendo muito eficientes nesses casos, como o cenóbio, a erva-de-passarinho, o agrimono, a melissa, o morrião; o anarcádio é indicado como tendo propriedades maravilhosas, mas ele tem poucas qualidades ativas; e as experiências de outros lugares não foram satisfatórias; chamava-se anteriormente antídoto dos Sábios; Hoffman o chamou de antídoto dos Loucos.

A experiência foi mais decisiva a favor de outros remédios, como o almíscar, a cânfora e os narcóticos. O almíscar, dado em doses fortes de até um escrópulo por dia, e a cânfora, administrada em baixa dose, foram aplicados com sucesso pelos Médicos ingleses e alemães; e a eficácia desses remédios em todas as outras doenças nervosas permite ainda mais a confiança que inspiram esses fatos. Sydenham recomendava calmantes junto com os cardíacos, mas somente os recomendava depois dos laxantes fortes. Wepfer tinha muito mais confiança nos calmantes, pois ele dava ópio todos os dias aos Maníacos. Depois de ter começado com uma dose de dois grãos, acabava dando 15. Este excelente Observador garante ter curado vários Maníacos por este método, sem ter feito as sangrias antes.

Enfim, o acaso fez conhecer os bons efeitos dos narcóticos prescritos com dose forte. Lemos o seguinte nos Atos dos Eruditos de Leipsick: demos a uma moça maníaca uma onça de unguento onde havia um escrópulo de ópio, para que ela friccionasse a têmpora: a Insana engoliu este unguento e foi curada imediatamente.

Os banhos de mar também foram aplicados, tanto para a mania como para a hidrofobia; mas eles só provocaram medo, o que foi mais prejudicial do que útil. Poderíamos aconselhar banhos frios, para causar febre artificial, como aconselhamos banhos de terra para a tísica: essa ideia é reforçada pelo fato de termos visto a mania ter sido curada pela febre ou por outra doença; e quando os maníacos são atingidos por uma doença da qual vão morrer, recuperam a razão no momento em que, com frequência, os outros homens a perdem nos mesmos casos.

A eletricidade produziu algumas variações nos Maníacos, mas não obtivemos nenhuma cura por este meio ainda.

Se o tratamento que acabamos de expor convém, com algumas exceções que foram mencionadas, a um maior número de Maníacos, há alguns tipos dessa doença para os quais será muitas vezes nocivo.

Rev. Latinoam. Psicopat. Fund., São Paulo, v. 15, n. 1, p. 113-137, março 2012 


\section{Espécies de Manias que exigem uma modificação particular no tratamento}

Estas espécies de mania, que exigem ainda mais modificações no tratamento podem se referir a três tipos: a que vem da inanição, a que é produzida pelas paixões da alma e a que é causada por venenos.

\section{Mania de inanição}

Sydenham foi o primeiro a notar a mania causada por inanição; ela sucede ao paludismo ou à febre intermitente outonal, ou a outras doenças cuja cura operada por um número excessivo de sangrias e por evacuações. Os doentes mostram no rosto todos os sinais de esgotamento; mas reconhecemos principalmente esta mania quando as mais leves evacuações a aumentam e a renovam. Uma simples lavagem de leite, no parecer de Sydenham, pode curar esta mania, relaxando o ventre: é evidente que será preciso procurar os remédios adequados a este tipo de mania nos analépticos, como o arroz, cevadinha, ovos frescos; os cordiais, como o bom vinho e águas destiladas cordiais; os tônicos, como a quinina; os fortificantes junto com os calmantes, como a teriaga. Sauvages relata que um Anatomista de reputação, em Montpellier, de sessenta anos, adoeceu desse tipo de mania e só foi curado devido ao escórdio e ao extrato de meimendro.

\section{Mania de paixões}

Todas as paixões muito ativas ou prolongadas podem gerar mania; mas há algumas que têm especialmente este triste poder: o estudo contínuo leva ao êxtase e do êxtase à mania só há um passo.

Van-Swieten observou que a cólera ou o pesar eram frequentemente a causa da mania que aparece nas parturientes. Os Hospitais estão cheios de desafortunados a quem a ambição ou ideias místicas fizeram perder a cabeça: a maioria destas manias são tristes e sombrias; há outras alegres. A mania que nasce do amor tem todo tipo de características; ou ela é viva e alegre, ou sombria e melancólica; algumas vezes, ela se torna furiosa. Em cada um destes tipos, é preciso aplicar as regras prescritas para o tratamento da mania, com as modificações indicadas para cada uma delas.

Nas mulheres que são atingidas pela mania durante o parto, se a mania é recente e elas gozam de certa força, a sangria é necessária e deve até ser repetida várias vezes se os lóquios são extintos. A violência do mal exige então que se dê mais atenção ao efeito do que à causa: nas que a doença é mais antiga, ou menos 


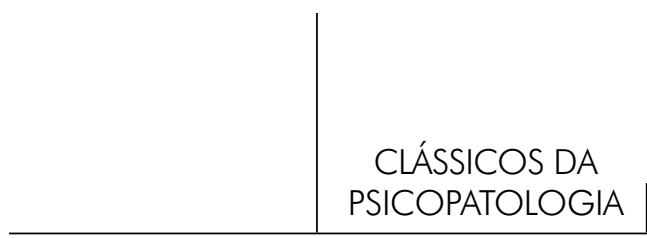

pletórica, os laxantes serão mais eficazes; e após pouco tempo, se não forem curadas, umas e outras entrarão no tipo dos Maníacos dos quais já falamos acima.

A erotomania quase sempre acontece entre os jovens e a caminhada ativa é necessária; mas é preferível multiplicar as duchas do que aplicar sangrias muito frequentes e muito fortes. Há ainda outra precaução importante, a de vigiar atentamente estes doentes; a lascívia, que é um sintoma comum a todos os Maníacos, chega a um ponto extremo e se eles se abandonam a ela, enfraquecem de forma incurável. Os remédios que abaixam a efervescência do sangue e o fogo da imaginação, as sangrias, os banhos, as duchas, as bebidas frias emulsionadas, serão os primeiros empregados; em seguida, os diluentes, os fundentes aperitivos e os laxantes que dão a fluidez aos humores. Com frequência, diz Lorry, a sarna, impingem ou outra afecção impetiginosa curou esta mania. Renovamos facilmente esta observação entre as mulheres afetadas de furor uterino; porque entre a maior parte delas, o mal começou pelo depósito de uma matéria acre e irritante nas partes da geração.

Necessidade mais urgente para isolar esses doentes

São especialmente os Maníacos que perderam a razão pelas paixões que precisam ser isolados e reanimados tanto quanto possível; porque eles estão mais expostos do que todos os outros ao contágio da imitação. Vanhelmont relatou que soube por vários Maníacos intermitentes que o acesso começava pela contemplação de uma ideia única que os perseguia por toda parte, e que eles viam sem cessar, como se ela estivesse presente em um espelho; é natural acreditar que esta imagem única e ameaçadora é mais forte ainda entre aqueles em que a mania é de origem moral.

\section{Mania de venenos}

$\mathrm{O}$ que as paixões germinam em nossas veias, as plantas venenosas e outros venenos podem produzir subitamente; o suco de stramónio e de hyoscyamus, as bagas de solanum, o lignum colubrinum, produzem realmente um delírio passageiro nas pessoas mais robustas e uma forte mania nas pessoas delicadas; as pessoas que tomam uma dose forte ficam alucinadas e Maníacas, caindo em seguida em sonolência ou em convulsões fatais; quando a dose é média, a mania é passageira, especialmente se remediarmos prontamente. Os sintomas desta mania são sucessivamente amedrontadores e ridículos, os doentes, animados por uma imaginação bizarra, correm atrás de entes quiméricos; algumas vezes dançam, cantam e se fantasiam de maneira grotesca; outras vezes ficam furiosos, se 
machucam mortalmente e não poupam os que encontram. A embriaguês de nosso país indica muito bem a primeira fase desta mania, enquanto a última fase só se vê no Oriente, onde os Muçulmanos fanáticos se embebedam de ópio, a ponto de sair como furiosos, para matar quem estiver por perto. O tratamento deste tipo de mania consiste inicialmente na administração de eméticos e em seguida de grandes quantidades de bebidas com ácidos vegetais: se a doença for grave, é preciso tratá-la como apoplexia, sangrar uma ou duas vezes, insistir nas lavagens purgativas, dar uma decocção de sena para beber e aplicar vários vesicatórios.

Não mencionamos a mania produzida por um defeito orgânico, nem sobre a que é causada por vermes no cérebro, porque o diagnóstico é difícil e a cura impossível. A mania hereditária é do mesmo tipo, a menos que ela seja um produto da fraqueza, o que a classificaria como mania de fraqueza de Sydenham. Poderíamos acrescentar a esta hipótese o uso de águas termais sulfurosas, no interior e no exterior.

A mania que é o resultado de uma pancada e de uma queda e deve ser tratada pelo método geral; se houver suspeita de cárie ou de abscessos, poderemos tentar a trepanação.

\section{Terceiro tipo. Melancolia}

A Melancolia é um delírio contínuo que difere da mania em duas coisas: primeiro, o delírio melancólico se limita a um só objeto chamado de ponto melancólico; segundo, esse delírio é alegre ou sério, mas sempre pacífico; assim, a melancolia difere apenas mais ou menos da mania e isto é tão verdadeiro que vários Melancólicos se tornam Maníacos e que vários Maníacos semicurados ou no intervalo de seus acessos, são Melancólicos.

\section{Características da Melancolia}

A melancolia se origina de uma sensibilidade moral demasiadamente grande ou muito forte que faz com que se atribua a um objeto qualquer um preço muito alto ou uma atenção fixa por um período de tempo excessivo; o que faz com que não se veja este objeto no seu verdadeiro contexto. Uma fibra delgada, os nervos móveis demais, a ociosidade, uma vida sem atividade, meditações metafísicas, pesares profundos devorados em longos silêncios, eis a causa desta primeira impressão da mente, que é a fonte da melancolia. Talvez se tenha dado erroneamente o nome de melancolia nervosa; mas se a consideramos como doença primária ou como resultado das causas que predispõe à melancolia, isto

Rev. Latinoam. Psicopat. Fund., São Paulo, v. 15, n. 1, p. 113-137, março 2012 


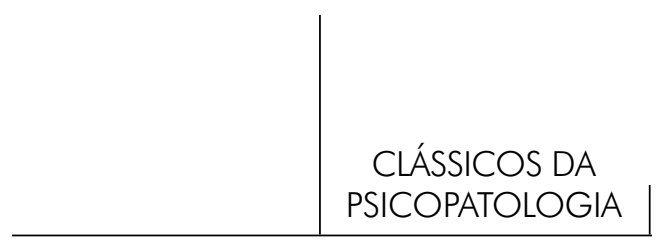

é indiferente, pois a melancolia nervosa produz sempre nos humores uma depravação humoral que age especialmente na bílis, e que sempre foi denominada melancolia; que ela consiste no espessamento do sangue impregnado de um humor estranho, pegajoso e incolor; que o efeito deste humor heterogêneo é de enviscar o ventre, diminuindo as excreções e secar o cérebro, enviando a ele vapores ou privando-o de sua parte mais fluida.

A melancolia nervosa não é nada além que o resultado das causas morais que produzem a melancolia humoral

Causas materiais, ou natureza da melancolia

Sintomas da melancolia

Os sintomas da melancolia são a magreza, tez escura, verde ou chumbada, manchas marrons e algumas vezes excrescências adiposas que se tornam amareladas: elevação dos hipocôndrios, gazes, borborigmos, ansiedade, constipação, evacuações pegajosas, urina amarelo-esverdeada, palpitações, entupimento de nariz, tristeza, irascibilidade, esquisitices que aumentam constantemente e, por último, a preocupação habitual com um objeto religioso ou moral, de saúde, físico, e ideias erradas e ridículas sobre este objeto.

\section{Tratamento da melancolia}

Cabe à sociedade curar as causas morais que provocam esta triste doença e é ela que deve arrancar essas ervas daninhas enquanto são tenras; mas podemos considerar aqui essa doença apenas no momento em que ela requer ajuda da Medicina, ou seja, quando ela estiver instalada.

Quando os acessos são violentos, a pessoa é pletórica ou em circunstância nas quais pode ocorrer um fluxo sanguíneo, como na idade crítica das mulheres, no final das regras, dos lóquios ou em outro caso semelhante, é preciso fazer sangria sem hesitação. Lorry não exclui nem mesmo as pessoas cujos nervos são móveis e delicados. Sydenham diz que fazia sangria amplamente e com sucesso na afecção histérica e hipocondríaca; podemos ainda acrescentar que a magreza não deve iludir; embora magros, esses doentes são muito sanguíneos, seu pulso rijo e forte e sem uma ou duas sangrias, os remédios de que necessitam não fariam efeito. 
Como fazer a sangria

Os laxantes devem ser tardios, qual é a maneira de usá-los

Mas após a sangria, é preciso evitar, nessa doença, de passar imediatamente aos laxantes, sejam quais forem. A causa material da doença, que deve ser combatida com todos os meios, é um humor tenaz, pegajoso que obstrui as vísceras e cobre o canal intestinal; mas, ao mesmo tempo, a fibra é irritável, o tipo nervoso muito móvel: em tal disposição, para que serviriam os laxantes? Somente aumentariam o mal: só as partes mais líquidas seriam excluídas; o núcleo ficaria mais duro e a tensão espasmódica mais forte. Assim, antes de purgar, é preciso diluir, dissolver e fundir este humor viscoso que é o princípio da doença; o procedimento posterior é conhecido. Tisanas levemente desobstruentes, soro do leite, um pouco de cremor de tártaro, banhos mornos, um regime umectante: passaremos em seguida aos fundentes mais ativos, como os sucos de ervas, bolos ensaboados, pílulas compostas de goma de amoníaco, cremor de tártaro e mercúrio doce; enfim, quando o humor ficar móvel, o que se notará quer pela natureza e abundância das excreções, quer pela diminuição dos sintomas, poderemos purgar e aplicar os purgativos numa sequência rápida. As águas minerais desobstruentes e ferruginosas são muito recomendadas na convalescença desta doença. Se não se notar melhora ou ela não se mantiver, faremos um tratamento antiflogístico; depois dos diluentes, aplicaremos laxantes mais fortes, aumentando os graus de eficiência até o uso do heléboro, como na Mania. A ducha, o sedenho e outros meios ulteriores citados no artigo precedente seriam usados como último recurso.

\section{Quarto tipo. A imbecilidade. Característica da imbecilidade}

A imbecilidade, que é o grau menos assustador e perigoso da loucura, é, aparentemente, a julgar bem, o mais deplorável estado de espírito porque é difícil de curar. Os Imbecis não são nem agitados, nem furiosos; raramente tristes, mostram um rosto estupidamente alegre e são mais ou menos os mesmos, na alegria e sofrimento. A imbecilidade é a sequência do Frenesi, da Mania, da Melancolia longamente prolongada. A secura do cérebro se encontra nos velhos; a moleza ou infiltração desta víscera a faz aparecer nas crianças; as pancadas, os chutes, o abuso de bebidas alcoólicas, a masturbação, um vírus transmitido são as causas rotineiras e ela é uma sequência comum da apoplexia. 


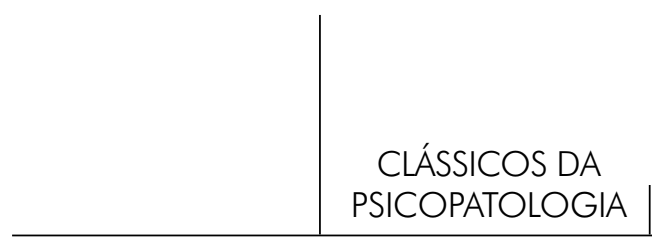

Causas da imbecilidade

A imbecilidade como resultado de um transtorno mental

Quando este estado é a sequência ou o último período de outra doença, há pouca esperança. A fibra perdeu seu vigor, os nervos estão sem energia, o sangue está meio decomposto e as forças já estão esgotadas pelos remédios que os doentes tomaram. Porém, a humanidade exige que não se abandone estes infelizes e esta atenção é ainda mais necessária quando vemos, às vezes, curas acontecerem com o tempo, só pelas forças da Natureza. A primeira coisa a fazer é fortalecê-los com uma boa alimentação; depois, eles tomarão águas termais artificiais, purgaremos com raiz de brionia e jalapa em infusão na aguardente, chamada de aguardente da Alemanha e tentaremos o que podem fazer os banhos frios e as duchas. Se estes doentes estiverem esgotados pelos remédios anteriores, ou se tiverem uma constituição mais fraca, serão tratados como Maníacos de inanição e faremos choques elétricos, cuja utilidade, nestes casos de fraqueza e apatia, foi demonstrada sem que haja nenhum risco.

Imbecilidade de esgotamento

A imbecilidade produzida pela masturbação só pode ser atacada por analéticos, tônicos, águas termais, fricções secas e não há inconveniente em tentar a eletricidade.

\section{Imbecilidade traumática}

As pancadas e os chutes só produzem Imbecilidade por abscessos, cáries ou extravasamento seroso: se não ousarmos tentar o trépano, poderemos pelo menos aplicar cautérios atrás das orelhas; alguns Autores até propuseram aplicar moxa na cabeça. Os antigos aplicavam fogo ao longo da espinha, com uma ousadia que nos faz tremer, mas tinham mais sucesso do que nós nas doenças que achamos incuráveis. Se as pessoas são robustas, os laxantes não são contraindicados e escolheremos os mais fortes.

Imbecilidade transmitida por um vírus

Se suspeitamos que um vírus transmitido é a causa da Imbecilidade, não há nada melhor do que inocular a sarna, e este meio poderia ser tentado em todos os Imbecis, quando o que acreditávamos que fosse o mais eficaz não produziu efeito. Não somente conjeturamos que vários destes doentes estariam bem na 
revolução operada pela nova doença, mas poderíamos esperar que os laxantes que usaríamos a seguir para curar a sarna, seriam vantajosos para alguns: se o vírus transmitido fosse de uma úlcera, empregaríamos os meios adequados para renová-la.

\section{Pelos venenos}

A embriaguês e os venenos causam uma imbecilidade passageira, que trataremos como a Mania; se ela persistir, exigirá laxantes e fortificantes.

Pela apoplexia

Enfim, a imbecilidade que é a sequência da apoplexia será atacada por cautérios, águas termais, laxantes fortes. A comoção elétrica será ainda mais recomendável neste caso, pois vários membros estão normalmente paralisados; algumas observações modernas provam que a tintura de cantárida é eficaz em circunstâncias semelhantes; mas é um remédio delicado, que só pode ser administrado sob o controle de um médico prudente e esclarecido.

Segundo a edição INSTRUÇÃO SOBRE A MANEIRA DE GOVERNAR OS INSENSATOS, E de trabalhar para sua cura nos Asilos destinados a eles. Paris. Da Imprensa Real/ MDCC LXXXV.

Edição Paris, 1785 (edição original)

Descrição 44 p.

Nota Este texto foi publicado também (entre outros) por:

Paul Sérieux e Lucien Libert, em A Assistência e tratamento das doenças mentais no tempo de Luís XVI. Instrução impressa por ordem e à custa do governo sobre como governar e tratar os Insensatos, Paris, sociedade francesa de imprensa e de livraria, In-8 ${ }^{\circ}, 15$ p., 1915.

(Há um exemplar na Bnf: cote 8 -TE65-162, Tolbiac - Andar do jardim - Loja)

Claude Wacjman, Internar ou curar, Discurso sobre a loucura no fim do século XVIII, Saint-Étienne, Publicações da Universidade de Saint-Étienne, 117 p., 1991.

Rev. Latinoam. Psicopat. Fund., São Paulo, v. 15, n. 1, p. 113-137, março 2012 
(Há um exemplar na Universidade de Pau e no Pays de l'Adour, S.C.D. cote UL 50388)

Um exemplar da edição original (1785) está na BNF

(Cote; TE66-1, Tolbiac - Andar do Jardim - Loja)

Um exemplar da edição de 1786 está na Biblioteca Municipal de Marselha (Cote: 78376, antigo)

2003-2006 (C) http://du.laurens.free.fr

\section{Jean Colombier (1736-1789)}

Cirurgião-mor do exército, nomeado pelo rei Luis XVI inspetor geral dos hospitais civis e das prisões do Antigo Regime.

\section{François Doublet (1751-1795)}

Especialista em doenças venéreas, professor da Faculdade de Medicina de Paris e membro da Sociedade Real de Medicina, nomeado pelo rei Luis XVI inspetor adjunto dos hospitais civis e das prisões do Antigo Regime. 